\title{
Relationship between geohydrology and Upper Pleistocene-Holocene evolution of the eastern region of the Province of Buenos Aires, Argentina
}

\author{
Leandro Rodrigues Capítulo*, Eduardo E. Kruse \\ Consejo Nacional de Investigaciones Científicas y Técnicas (CONICET), Facultad de Ciencias Naturales y Museo, Universidad Nacional de La Plata (UNLP), 64 \\ $n^{\circ}$ 3, 1900 La Plata, Argentina
}

\section{A R T I C L E I N F O}

\section{Article history:}

Received 12 August 2016

Received in revised form

23 March 2017

Accepted 23 March 2017

Available online 27 March 2017

\section{Keywords:}

Coastal aquifer

Hydrofacies

Landscape evolution

Pleistocene

Holocene

\begin{abstract}
A B S T R A C T
The Upper Pleistocene-Holocene geological evolution, which is characterized by its landscape-forming energy and is related to geological and geomorphological complexity, has an impact on the groundwater dynamics of coastal aquifers. The geological configuration of a sector of the east coast of the Province of Buenos Aires was analyzed, as well as its connection with the geological and geomorphological history of the region during the Late Pleistocene and Holocene, and its influence on the regional and local geohydrological behaviour. This analysis was based on the application of the concept of hydrofacies. Boreholes were drilled and sampled (with depths of up to $40 \mathrm{~m}$ ), and vertical electrical sounding, electrical tomography and pumping tests were undertaken. The description of the cutting samples by means of a stereo microscope, the interpretation of satellite images, and the construction of lithological and hydrogeological profiles and flow charts were carried out in the laboratory, and then integrated in a GIS. The identification of the lithological units and their distribution in the area allowed the construction of an evolutionary geological model for the Late Pleistocene and Holocene. Three aquifer units can be recognized: one of Late Pleistocene age (hydrofacies $\mathrm{E}$ ) and the other two of Holocene age (hydrofacies $\mathrm{A}$ and $C$ ); their hydraulic connection depends on the occurrence and thickness variation of the aquitard units (hydrofacies B and D). The approach adopted allows the examination of the possibilities for groundwater exploitation and constitutes an applied conceptual framework to be taken into consideration when developing conceptual and numerical models at the local and regional scales.
\end{abstract}

(c) 2017 Elsevier Ltd. All rights reserved.

\section{Introduction}

Water demand for different uses has led to a progressive decrease in fresh groundwater reserves in coastal areas (Silva-Filho et al., 2009). These environments are characterized by a high vulnerability (White and Falkland, 2009), and the changes in groundwater dynamics caused by anthropogenic activity have an influence on the reserves and the chemical quality of water (Schneider and Kruse, 2006; Carol and Kruse, 2012).

Groundwater in these sectors has particular characteristics from the point of view of the origin and functioning of the natural littoral areas related to them. The effective management of such areas

\footnotetext{
* Corresponding author.

E-mail addresses: leandrorodriguescapitulo@gmail.com (L.R. Capítulo),kruse@ fcnym.unlp.edu.ar (E.E. Kruse).
}

requires a detailed knowledge of the geometry, origin and functioning of aquifers (Manzano, 2002). In South America, coastal aquifers have some common features, such as their intensive exploitation, the lack of characterization studies supporting the planning and management of resources, the lack of monitoring networks, and the need to raise awareness in society of this issue and its implications in resource planning (Bocanegra et al., 2009).

The lack of proper characterization is frequently associated with rudimentary geological knowledge that is not detailed enough to resolve basic issues connected to the management of water resources. In general, acquiring such geological knowledge is difficult in a coastal area, since there are no outcrops and the borehole data available must be relied upon-data that is conditioned by the density, depth and quality of such information.

The significant geological and geomorphological complexity that characterizes coastal regions is the result of the geological evolution during the Late Pleistocene-Holocene (Hirata et al., 
2011). This can be observed in hydrogeological variations that are often not easily interpreted.

The erosion, sedimentation or development conditions of the soil reflect particular hydrological situations and become relevant in the evaluation of the groundwater system, leading to a highly heterogeneous distribution of the hydrogeological parameters (Klingbeil et al., 1999).

The east coast of the Province of Buenos Aires is an example of the above-mentioned aspects and it is also characterized by a high population growth, which leads to a growing demand for drinking water associated with urbanization processes and the expansion of human activities (Carretero and Kruse, 2010, 2014). The sector under study consists of a series of seaside resorts that, according to a census carried out in 2010, has a stable population of 25415 inhabitants (INDEC, 2010) and that, in turn, in the summer season, receive more than 500000 tourists in a short period of time.

Based on the lithological data collected from the new boreholes, it is possible to gain an insight into the geological history and identify any anisotropies having an influence on groundwater flow. This, together with the measurement of hydraulic parameters, forms the basis for the identification of hydrogeological units according to their lithological characteristics. In this sense, the application of the concept of sedimentary units with a homogeneous hydrogeological behaviour, called hydrofacies following Anderson (1989), is of great relevance.

Numerous studies have been undertaken from this perspective, with the study by Klingbeil (1998) on Quaternary fluvial sediments deposited during the last glaciation in southwest Germany standing out among them. In that work, the sedimentological analysis of the deposits is approached as being analogous to an aquifer, assigning hydrogeological parameters to each of the sedimentary units, which allowed the modelling of groundwater flow and transport by means of such hydrofacies.

A similar analysis is carried out in Huggenberger et al. (1988), in which the sedimentological description and the measurement of the hydraulic parameters of the Pleistocene Rhine gravels make it possible to connect the geophysical observations with the hydrogeological characteristics of the groundwater system.

Another approach is applied by Scheibe and Freyberg (1990), who undertake an assessment of the geological component in the behaviour of the groundwater flow, laying particular emphasis on the processes that resulted in the geological structures in which the aquifer occurs and which condition the direction of the groundwater flow.

Other authors, such as Makkawi (2004), dell'Arciprete (2011), Modis and Sideri (2013) and Atkinson et al. (2014), complement the use of the concept of hydrofacies with the application of techniques of geostatistical simulation for the modelling of groundwater flow in aquifers with heterogeneous geological and hydraulic characteristics.

The objective of this work is to analyze the implications of the hydrofacies defined for the regional and local geohydrological behaviour of a sector of the east coast of the Province of Buenos Aires, on the basis of the geological configuration and its relationship with the geomorphological history during the Upper Pleistocene and Holocene.

\section{Study area}

The study area (Fig. 1 ) is located on the eastern edge of the Province of Buenos Aires in Argentina (37 $6^{\prime} 36.66^{\prime \prime} \mathrm{S} ; 56^{\circ} 52^{\prime}$ 17.83 " W). From a hydrogeological point of view, it is part of the Región Costera (Coastal Region; González, 2005) and, as regards its geomorphology, it is within the limits of the Cordón Costero Medanoso (Coastal Sand-dune Barrier; Parker and Violante, 1989).
It covers an area of $66.2 \mathrm{~km}^{2}$ and comprises the towns and cities of Montecarlo, Pinamar, Valeria del Mar, Cariló, Ostende and Mar de Ostende.

Regionally, the study area is in the southern sector of the Salado Basin geological province (Rolleri, 1975). It consists of a depositional basin that extends from the northern tip of the Province of Buenos Aires in a southeasterly direction until it penetrates into the Argentine continental shelf to the southeast of the Samborombón Bay. Its development is related to the structural control due to extensional fracturing of ancient weak zones originating in the opening of the South Atlantic during the late Mesozoic (Caminos, 1999).

The Quaternary geological history of the area under study is inextricably linked to the geodynamic control of factors related to transgressive and regressive events caused by sea-level oscillations. Evidence of such level variations can be found in different parts of the planet. During the Last Interglacial (125 $000 \mathrm{BP})$, the sea level reached a global maximum of $6 \mathrm{~m}$ above the present-day mean level in different regions (Barbados, the Bahamas, Molokai in Hawaii, and the east coast of South America, among others) (Lowe and Walker, 1997; Schnack et al., 2000).

In Argentina, there are records of transgressive and regressive events in the Pleistocene and Holocene, connected to the glacial and interglacial cycles. Besides, the occurrence of significant tectonic processes during the development of the coastal environments in the last 120000 years are discarded (Schnack et al., 2005).

There have been numerous contributions that aimed at describing the geological history of the eastern sector of the Province of Buenos Aires. During the Quaternary transgressions, accumulation and erosion processes-caused by the variations in the coastline-affected extensive sectors of the littoral of Buenos Aires. These advance and retreat events generated deposits represented by marsh, estuary, coastal lagoon, coastal dune and beach deposits, and even storm facies characterized by a high mollusc shell content.

Evidence of transgressive events on the coast of Buenos Aires has been preserved in the stratigraphic record and has been given several names, such as, Querandinense and Platense (Frenguelli, 1957), Samborombonense (Groeber, 1961), Destacamento Río Salado and Las Escobas Formations (Fidalgo et al., 1973), Atalaya Formation (Parker, 1990), Las Escobas and Espinillo Formations (Cavalloto, 1995), and Campana Formation (Fucks and De Francesco, 2003).

Towards the end of the last glaciation (18 $000 \mathrm{BP}$ ), the global sea level fell by $120-150 \mathrm{~m}$, to coincide with the present-day edge of the continental shelf (Fray and Ewing, 1963; Parker et al., 1996), and vast expanses of land were exposed.

During the period of 18000 to 7000 years BP, the greatest contribution of the melting of ice occurred. In general, there is consensus on the culmination of the global sea-level rise, which occurred 7000 to 6000 years BP (Jelgersma and Tooley, 1995).

As from that moment, regional and local processes dominated the sea-level record, which is why the curves of sea-level rise in time are sometimes divergent and variable (Jelgersma and Tooley, 1995). On the other hand, works undertaken on the east coast of the Province of Buenos Aires by Cavalloto (1995), Cavalloto et al. (2004), Isla and Espinosa (1998) and Spagnuolo (2005) agree on a falling relative sea-level curve initially located between 4 and $5 \mathrm{~m}$ a.s.l.

Recent works, such as the ones undertaken by Pousa et al. (2007) and Tosi et al. (2013), agree that the trend in the last century indicates a relative sea-level rise curve. According to the data available, it can be estimated that the average rise value is of the order of $1.4 \pm 0.4 \mathrm{~mm} / \mathrm{yr}$ in the area under study. The present-day coastal dynamics has a microtidal regime $(<2 \mathrm{~m})$ with diurnal inequalities, whereas the longshore drift in general occurs from south to north (Isla and Bertola, 2005). 


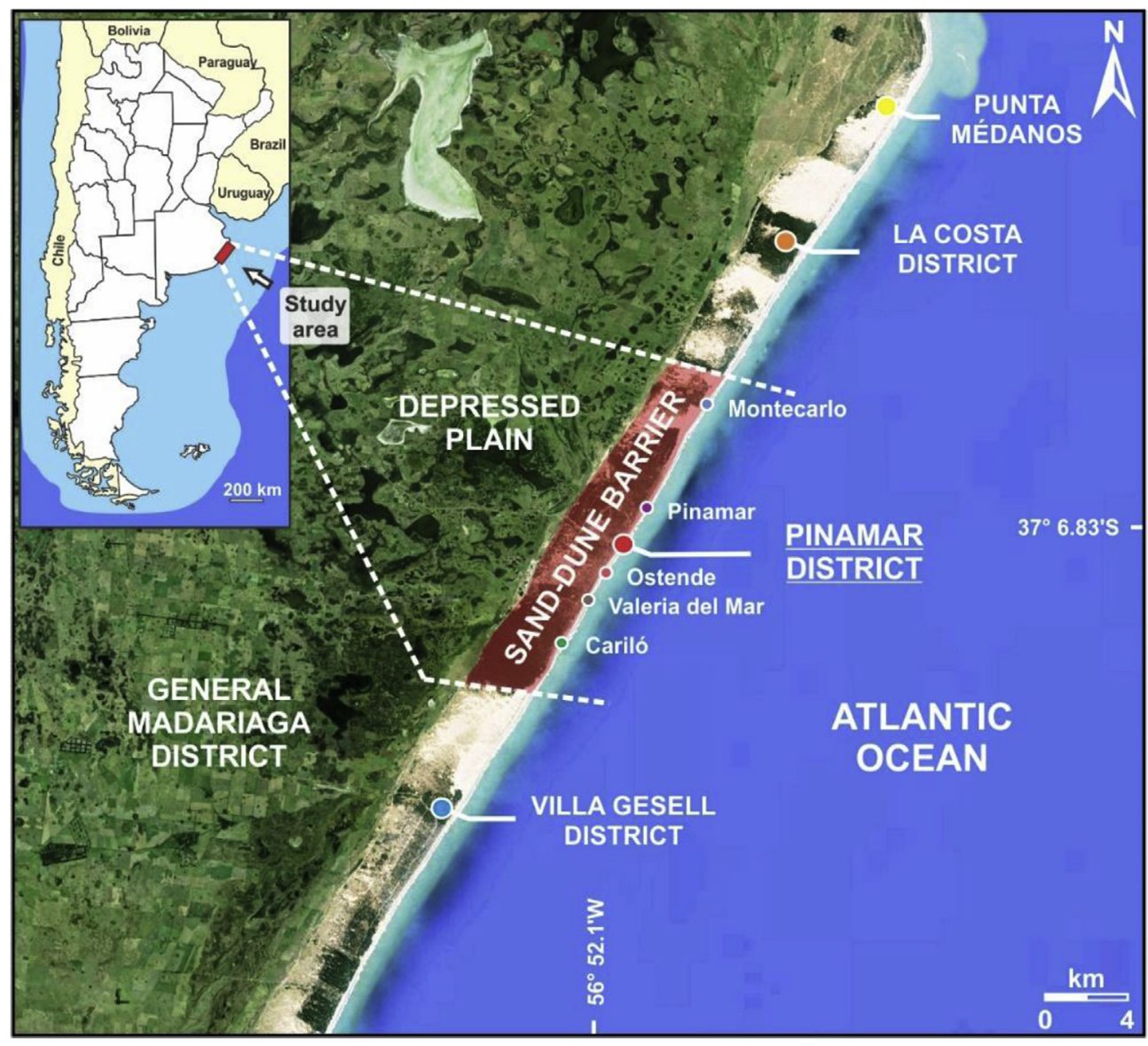

Fig. 1. Study area.

\section{Materials and methods}

Subsurface exploration was undertaken by means of handoperated and rotary drilling systems using drilling mud. In both cases, the sampling was done at wellhead, collecting sediment samples that were mesoscopically described in the field and prepared for the subsequent microscopic description in the lab. This work made it possible to have a detailed description of 47 boreholes, adding up to a total of $1260 \mathrm{~m}$ of drilling and $252 \mathrm{~kg}$ of cutting samples.

In order to obtain complementary information on the geological characteristics of the subsoil, geophysical exploration techniques were used. They consisted in 9 vertical electrical soundings (VES) and 14 electrical resistivity images (ERI) (Fig. 2).

Given the lack of a topographic map, it was necessary to carry out a survey based on the determination of the height of the wells by means of an optical level. The data obtained with a differential GPS made it possible to improve the vertical resolution of the map in the sectors that were harder to reach.

In order to integrate the above-mentioned data into a geographic information system (GIS), a plane projection system was chosen (Gauss-Krüger projection, datum Campo Inchauspe) and, as a base map, it included the satellite image of the area, the urban grid, the main occurring landforms, the lithological descriptions, and the location of the monitoring wells.

Based on the data obtained from the boreholes, ten integrated geological profiles were constructed; three of them were located parallel to the coastline, while the rest were perpendicular to it (Fig. 2).

Numerous pumping tests and level measurements were undertaken in the field, on the basis of which regional flow maps were drawn, and the permeability, transmissivity and storage ranges for each lithological unit identified were defined.

\section{Results}

\subsection{Regional geological and geomorphological framework}

The most outstanding geomorphological feature is the coastal barrier, whose greatest development follows a northeast-southwest trend, occurring between the depressed plain to the west and the Atlantic Ocean to the east. The landscapes identified show sand bodies of aeolian origin that define the interaction between the continental and marine processes (Fig. 3).

The landscape of the depressed plain (Fig. 4) is flat and frequently flooded, with mostly clayey soils (Vertisols) and smooth slopes. The topographic extremes are between 6.2 and $2.7 \mathrm{~m}$ a.s.l., whereas the average height is $4.3 \mathrm{~m}$ a.s.l. The coastal barrier develops as a strip parallel to the sea, with a width that ranges from $2.7 \mathrm{~km}$ in Montecarlo to $3.7 \mathrm{~km}$ in Pinamar. The eastern limit coincides with the seaside route (Ruta Provincial 11 [Provincial Route 11]), located at a height of $5 \mathrm{~m}$ a.s.l.

Generally speaking, in this coastal barrier, a beach area and a sand-dune area can be recognized (Fig. 3A and B). Beaches have an average width of $120 \mathrm{~m}$ and they are characterized by a broken profile, from which point the upper shoreface and foreshore, separated by a berm, can be differentiated.

The sand-dune unit flanks the beach unit to the west. At a regional level, this landform has a heterogeneous relief, with smooth, elongated hills in certain cases, whereas in others the 


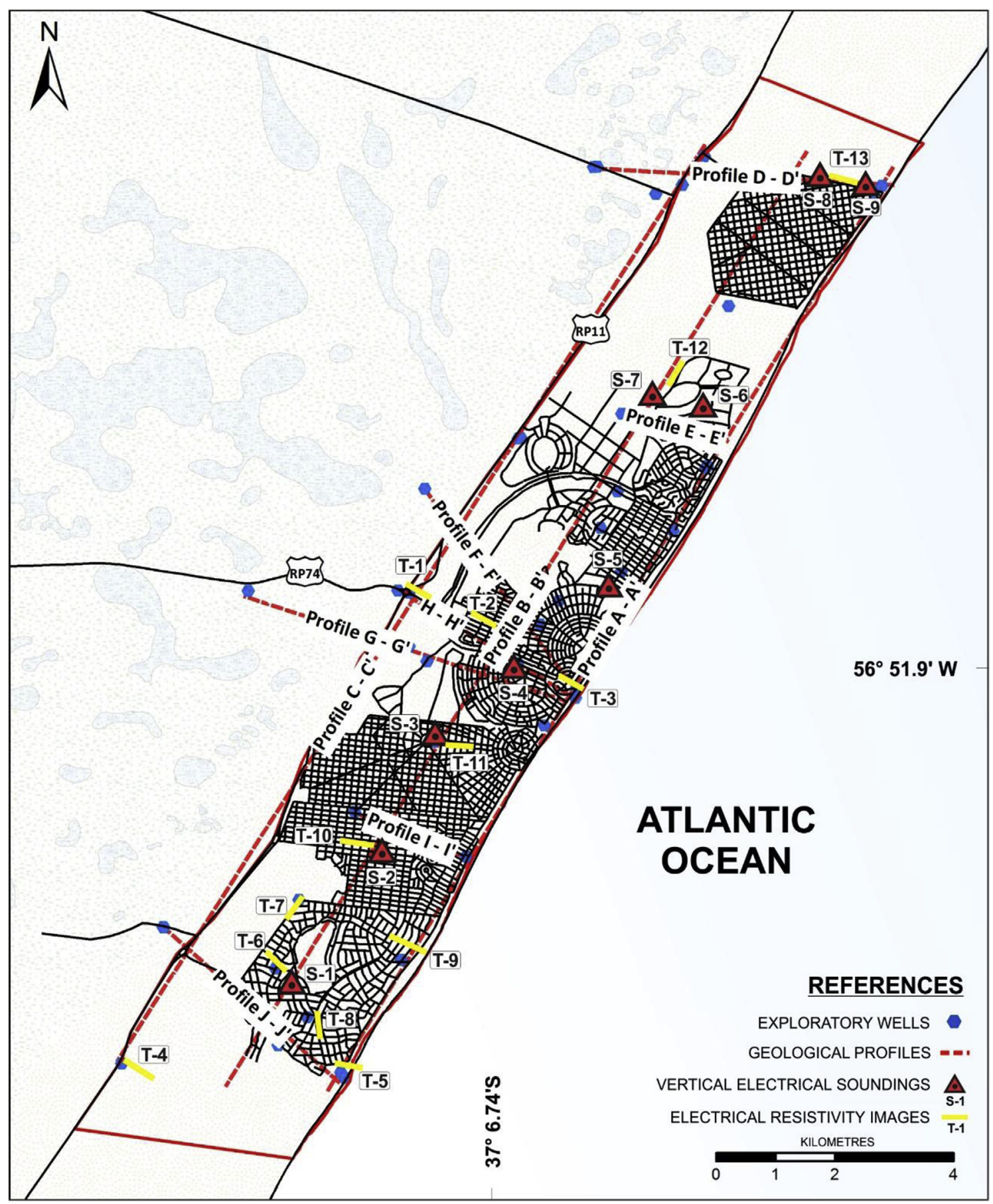

Fig. 2. Distribution and location of the integrated geological profiles, exploratory wells, vertical electrical soundings and electrical resistivity images.

height differences measured in relatively short distances range from 6 to $10 \mathrm{~m}$, creating depressions at a local level.

The topography (Fig. 5) is characterized by a convex transverse profile with a slight asymmetry made evident by the displacement of the axis of maximum barrier heights towards the west. The eastern slope is less abrupt than the western one. The average height is $10 \mathrm{~m}$ a.s.l., with extremes of 3 and $16 \mathrm{~m}$ a.s.l.

To the north, a group of topographic highs constitutes a sanddune field with no vegetation, covering an approximate area of $2.8 \mathrm{~km}^{2}$ (Fig. 6). In this sector, transverse dunes, barchans, barchanoids and even dunes fixed by vegetation occur. The detailed topographic surveys carried out in this sector allowed the differentiation of three main sand-dune fields, with maximum heights of
36,38 and $28 \mathrm{~m}$ a.s.l. from north to south. In these sectors, in the relatively wet periods, shallow lake bodies are formed, indicating that, at least temporarily, the water table rises.

The typical soils occurring in the barrier are Entisols characterized by limited soil development in a thickness of less than $40 \mathrm{~cm}$ and the presence of a histic A horizon in which the vegetation debris originates to a large extent from the exotic arboreal vegetation (conifers).

\subsection{Geoelectrical characteristics}

Based on VES, true resistivity models were obtained (Fig. 7) and they indicated high values in the UZ (unsaturated zone) 


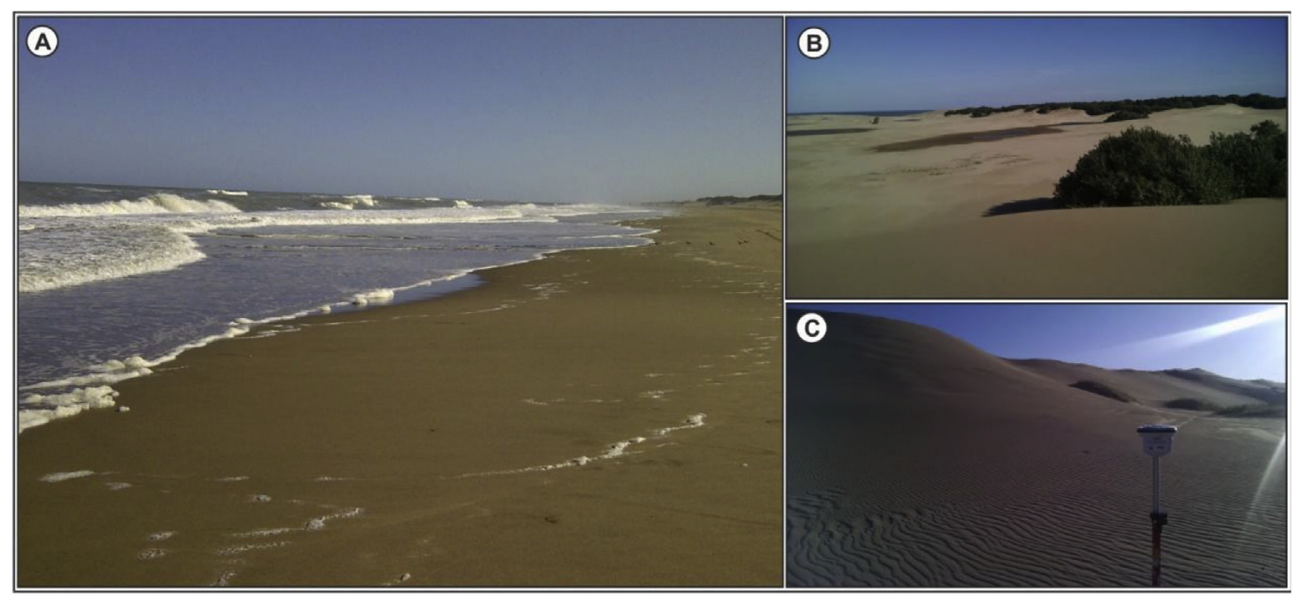

Fig. 3. Main landforms recognized in the sand-dune barrier. (A) Coastline, (B) Sand dunes fixed by vegetation, and (C) Sand-dune development.
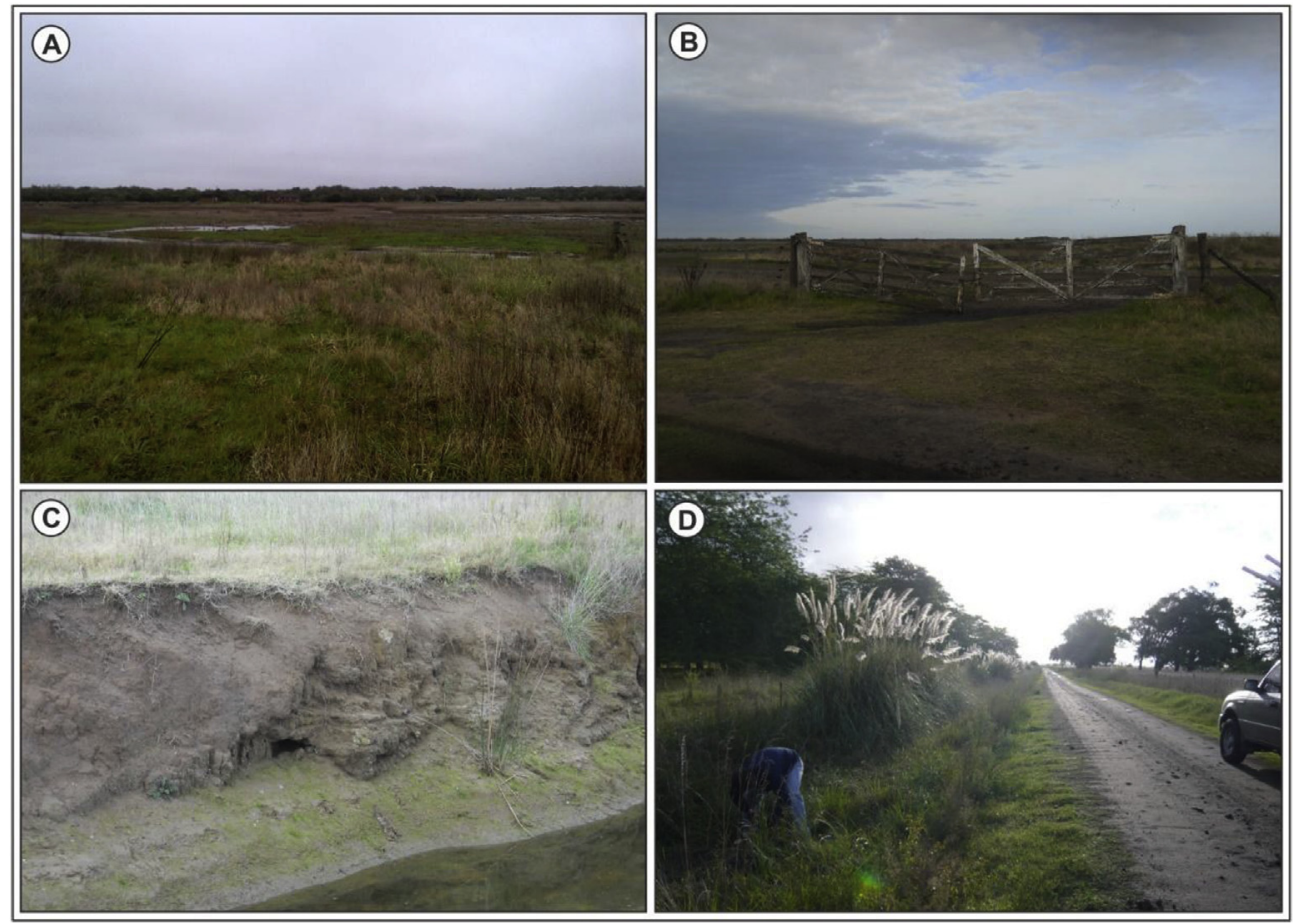

Fig. 4. Typical landscapes of the depressed plain.

(>300 $\Omega \mathrm{m}$ ). In the SZ (saturated zone), two or three layers with resistivity values within the $10-100 \Omega \mathrm{m}$ range can be recognized. The first layer, below the water table, has a mean resistivity of $100 \Omega \mathrm{m}$, whereas in the second layer, it is $25 \Omega \mathrm{m}$. No significant contrasts can be observed between the different electrolayers, which could be related to the lateral variations in lithology and to the transitional character between the units.

Electrical tomography ( $\mathrm{T}$ ) confirms such characteristics. In Fig. 7 b, c and d, representative examples of the eastern, central and coastal sectors of the sand-dune barrier can be observed.

T1, located $50 \mathrm{~m}$ away from Ruta Provincial 11, shows a profile whose most resistive values (higher than $200 \Omega \mathrm{m}$ ) indicate the UZ and make it possible to estimate a depth of $3 \mathrm{~m}$ for the water table, whereas the SZ shows resistivities within a range of 20-150 $\Omega \mathrm{m}$.

$\mathrm{T} 2$ (central sector of the sand-dune barrier) shows that the most resistive values extend to a depth of $15 \mathrm{~m}$, indicating the thickness of the UZ. This could be verified by means of a sounding. T3 (coastal sector of Pinamar) shows values higher than $150 \Omega \mathrm{m}$ in the upper left section, and they could be assigned to the UZ, with a thickness of $5 \mathrm{~m}$. Intermediate resistivities (20-150 $\Omega \mathrm{m}$ ) up to a depth of $20 \mathrm{~m}$ can be attributed to saturated sands with water with a low salt content. The analysis of the relatively most resistive values in the lower left sector of the profile makes it possible to assume the occurrence of a zone of freshwater discharge or transference towards the sea.

\subsection{Lithological units and subsurface configuration}

Based on the data obtained from the 47 boreholes drilled, 6 lithological units were identified. Following this criterion, the stratigraphic sequence, with a thickness of $45 \mathrm{~m}$, is composed of the following units. 


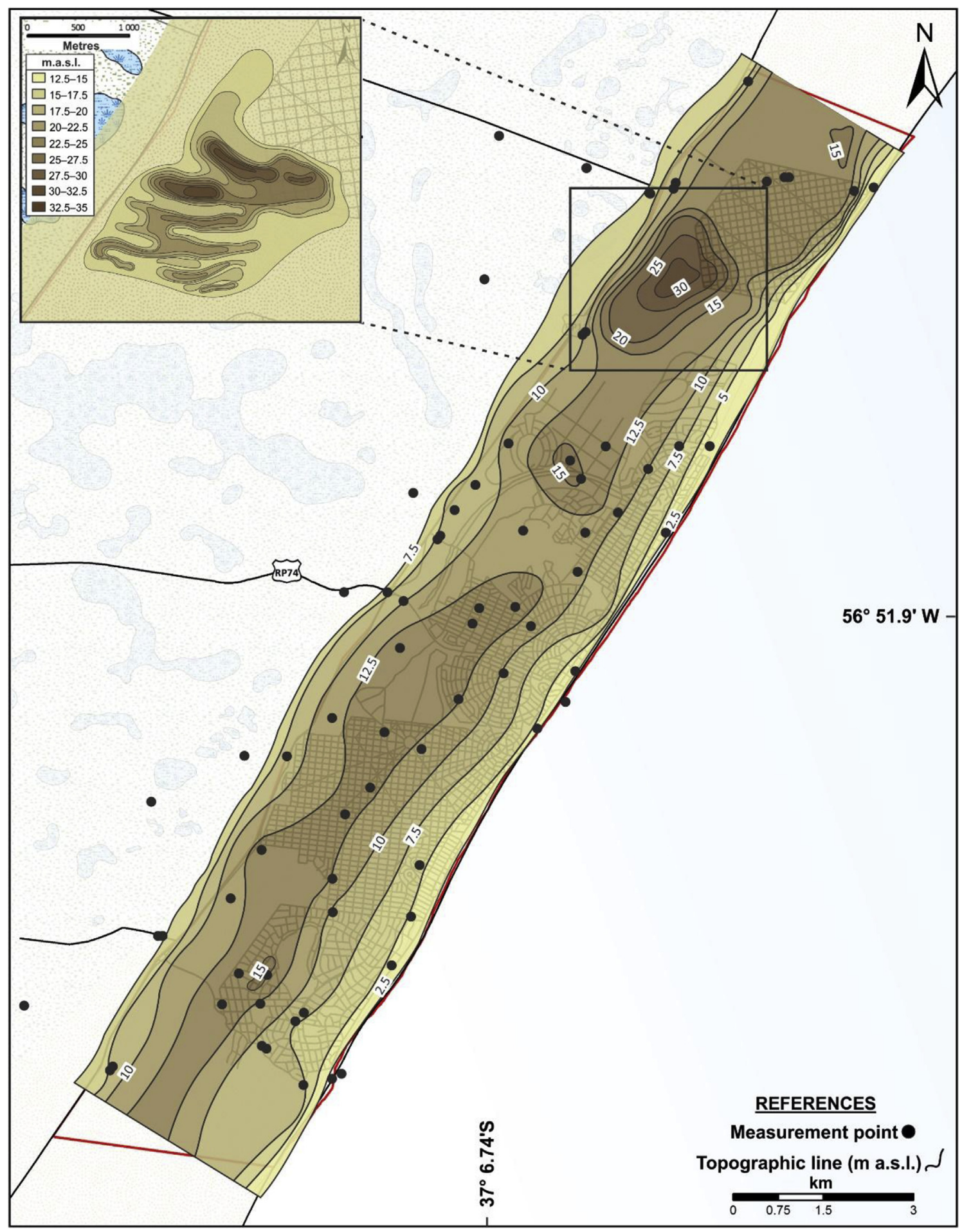

Fig. 5. Topographic map of the study area.

\subsubsection{Fine sand with shell fragments (FSSF)}

It consists of fine-to medium-grained sand with crushed shells and a thickness ranging from 2 to $15 \mathrm{~m}$. The greatest thicknesses occur in the central portions of the sand-dune barrier. In the sectors close to the coastline, a significant increase in the bioclastic fraction can be observed, in some cases almost constituting the entire unit.

The samples are light brown in colour, with subrounded grains and a high degree of sorting. The mineralogy consists of slightly variable amounts of quartz, mafic minerals and shell fragments that, in general terms, occur in ratios of 60:20:20 (quartz:mafic minerals:shell fragments), respectively. Mafic minerals are mainly opaque, whereas the bioclastic fraction shows great variability in size and it consists mainly of Holocene bivalve remains.

\subsubsection{Organic horizons $(\mathrm{OH})$}

This unit consists in thin levels $(<1 \mathrm{~m})$ composed of vegetation remains and variable quantities of dark grey clay. The maximum expression and frequency of these horizons occur in the central 


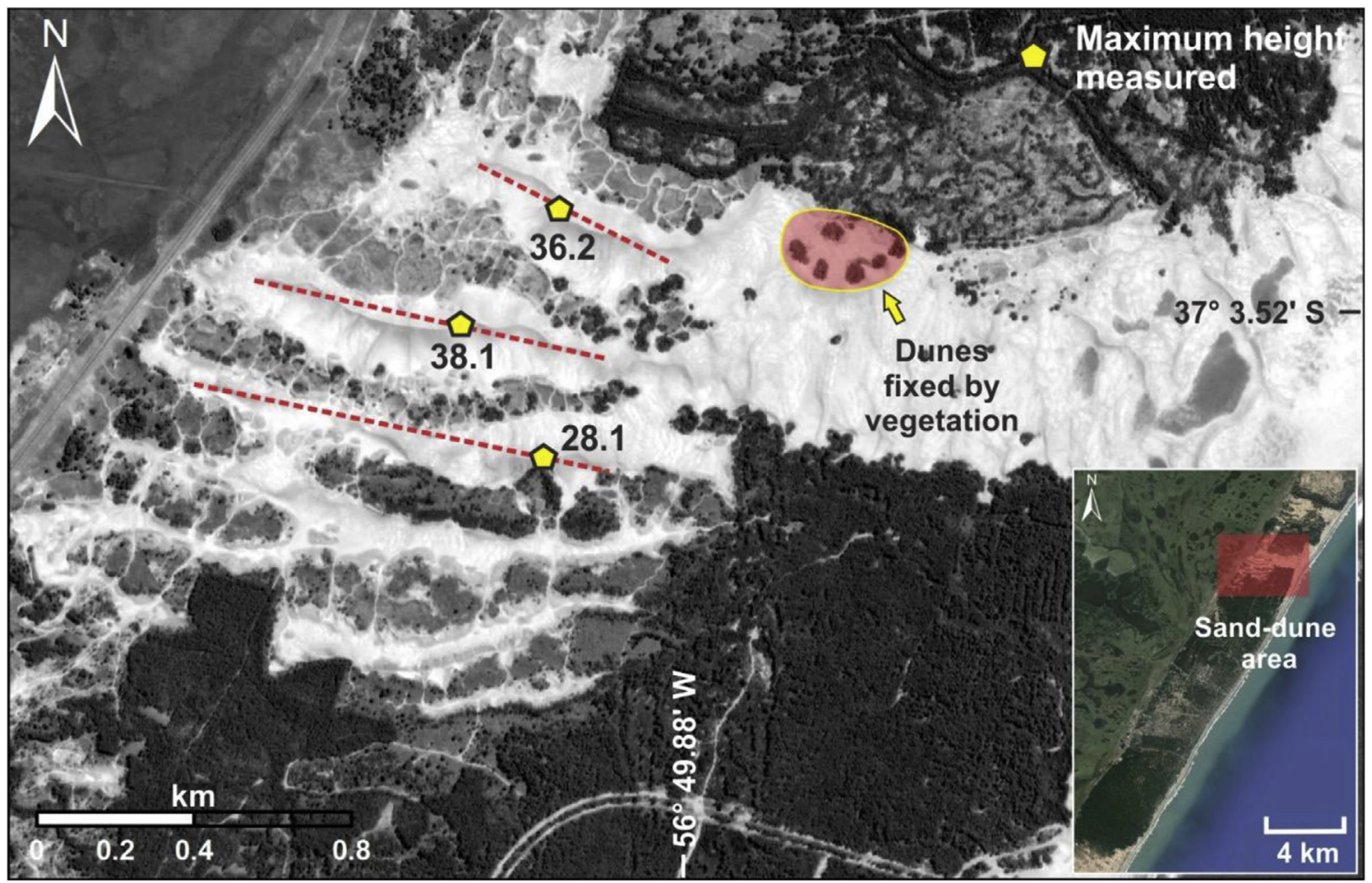

Fig. 6. Landsat-7 TM image (Path/Row: 223/086) of the sand-dune field in the north of the Partido de Pinamar (Pinamar District) taken on 25 March 2015

areas of the barrier and those adjacent to the seaside route (Ruta Provincial 11). Their fetid smell makes it possible to infer the degree of decomposition of the organic matter, which gives the sample a dark grey colour. The analysis with the stereo microscope allowed the identification of fibrous, amorphous organic matter, which constitutes between 40 and $60 \%$ of the samples in most cases.

\subsubsection{Grey clay with sandy intercalations (GCSI)}

This unit consists of greyish clays with fine-to very fine-grained sandy intercalations. In some sectors, the clay appears as a fraction subordinate to sand or as very thin laminar intercalations within the sandy sediment. This complex has its maximum expression in the central sectors of the coastal barrier, with thicknesses reaching $12 \mathrm{~m}$ and decreasing towards the coastline, where they tend to disappear. In exceptional cases, complete shells were found along with clay in the coastal sectors. This would explain the fact that these sediments are overlain by the shell fractions of FSSF. In the analysis with a stereo microscope, the plastic character of the clay can be recognized, as well as the composition of the clastic fraction, which is only composed of very fine grains of quartz, very well sorted and rounded.

\subsubsection{Medium-grained sand (MGS)}

This unit is characterized by medium-to fine-grained, brown to dark grey sand, with a very low percentage of gravelly material and variable proportions of shell fragments, which are highly fragmented. The distribution and thickness of this unit are irregular, with thicknesses ranging from a few metres up to $12 \mathrm{~m}$ in the central sectors of the barrier.

It differs from the FSSF unit in the larger grain size and the greater percentage of mafic components, with ratios of 50:35:15 (quartz:mafic minerals:shell fragments), which gives it a darker shade compared to the above-mentioned unit. Both the quartz grains and the mafic minerals are medium-to fine-grained and occur as subrounded, well sorted grains.

\subsubsection{Brown clayey silt with carbonate intercalations (BCSCI)}

This unit consists of brown clayey silt with different proportions of carbonates. The carbonate character is suggested by an effervescent reaction when in contact with hydrochloric acid. This lithology is the one with the greatest thicknesses of all the sedimentary profile, in certain cases reaching $40 \mathrm{~m}$. Under the stereo microscope, it was possible to verify the occurrence of quartz and mafic materials in the clastic fraction, which reaches up to $30 \%$ of the sample. The occurrence in the lithic fraction of both clayey silt and carbonates gives it a general light brown colour, which makes it possible to differentiate it from GCSI. Towards the end of the sequence, shell fragment layers of up to $2 \mathrm{~m}$ thick associated with coarse-grained mafic components are often recognized.

\subsubsection{Very fine-grained sand lenses (VFGSL)}

These thicker lenticular sandy intercalations occur within BCSCI and consist of sediments that range from very fine-grained dark sand to coarse silt with highly fragmented shells. The maximum development of the lenses can be observed in the coastal sectors, with thicknesses of approximately $20 \mathrm{~m}$, as described in Montecarlo.

In certain cases, these lenses have slightly different sedimentological characteristics, with clean, well sorted medium-grained sand of a light brown colour, a thickness not exceeding $7 \mathrm{~m}$ and a distribution restricted to Valeria del Mar, Ostende and Cariló.

\subsection{Upper Pleistocene-Holocene geological/geomorphological evolution}

According to the lithologies and stratigraphic relations identified, it is possible to describe the sector on the basis of four main stages of morphological evolution, which are represented in Fig. 8.

The associated BCSCI and VFGSL units are the result of a transgressive-regressive cycle (Fig. 8 I and II), which occurred during the Upper Pleistocene (MIS 5e). Within this scheme, BCSCI is the 

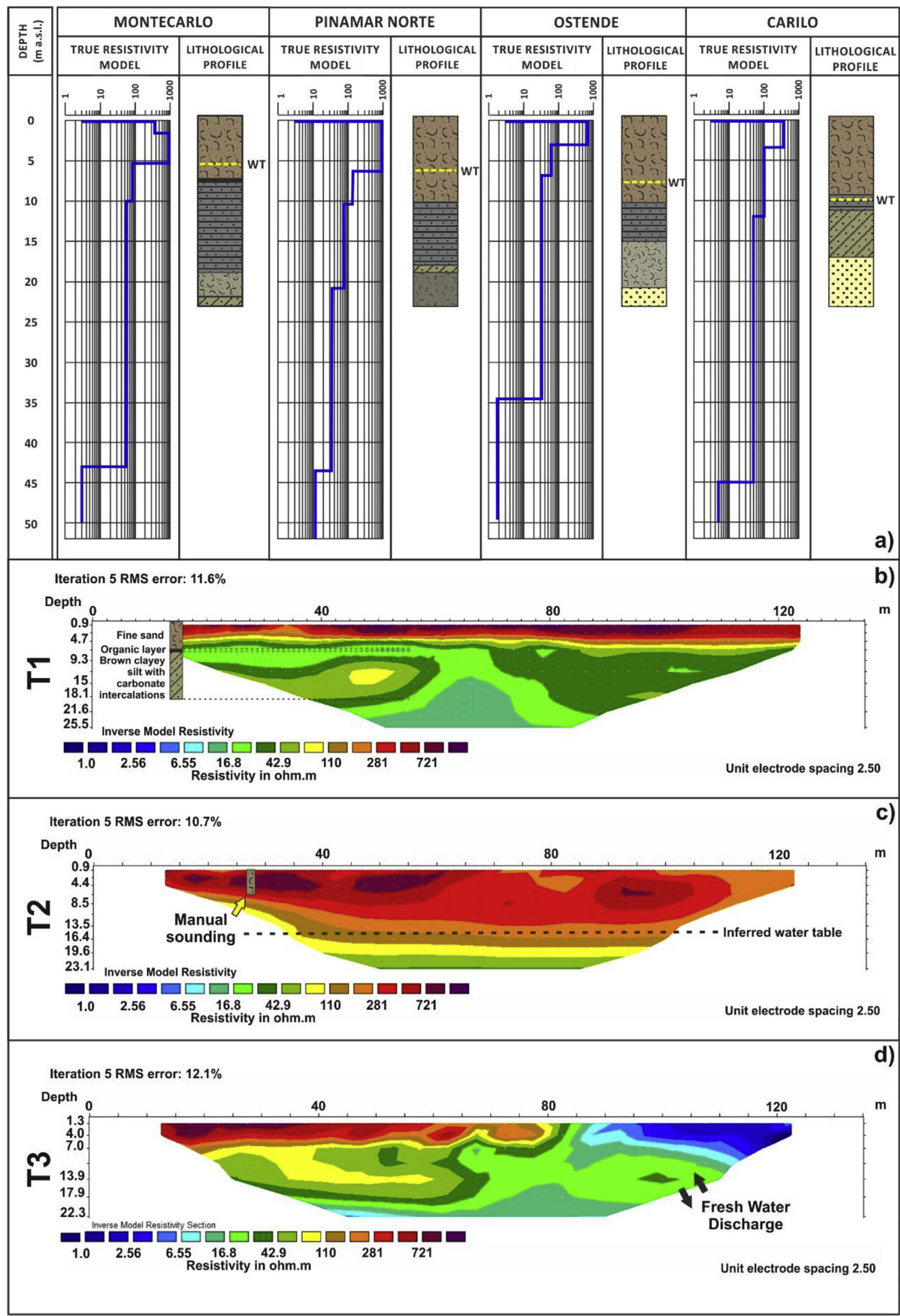

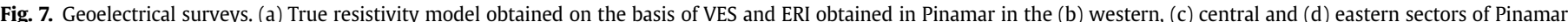
(see location in Fig. 2). WT: Water table. 


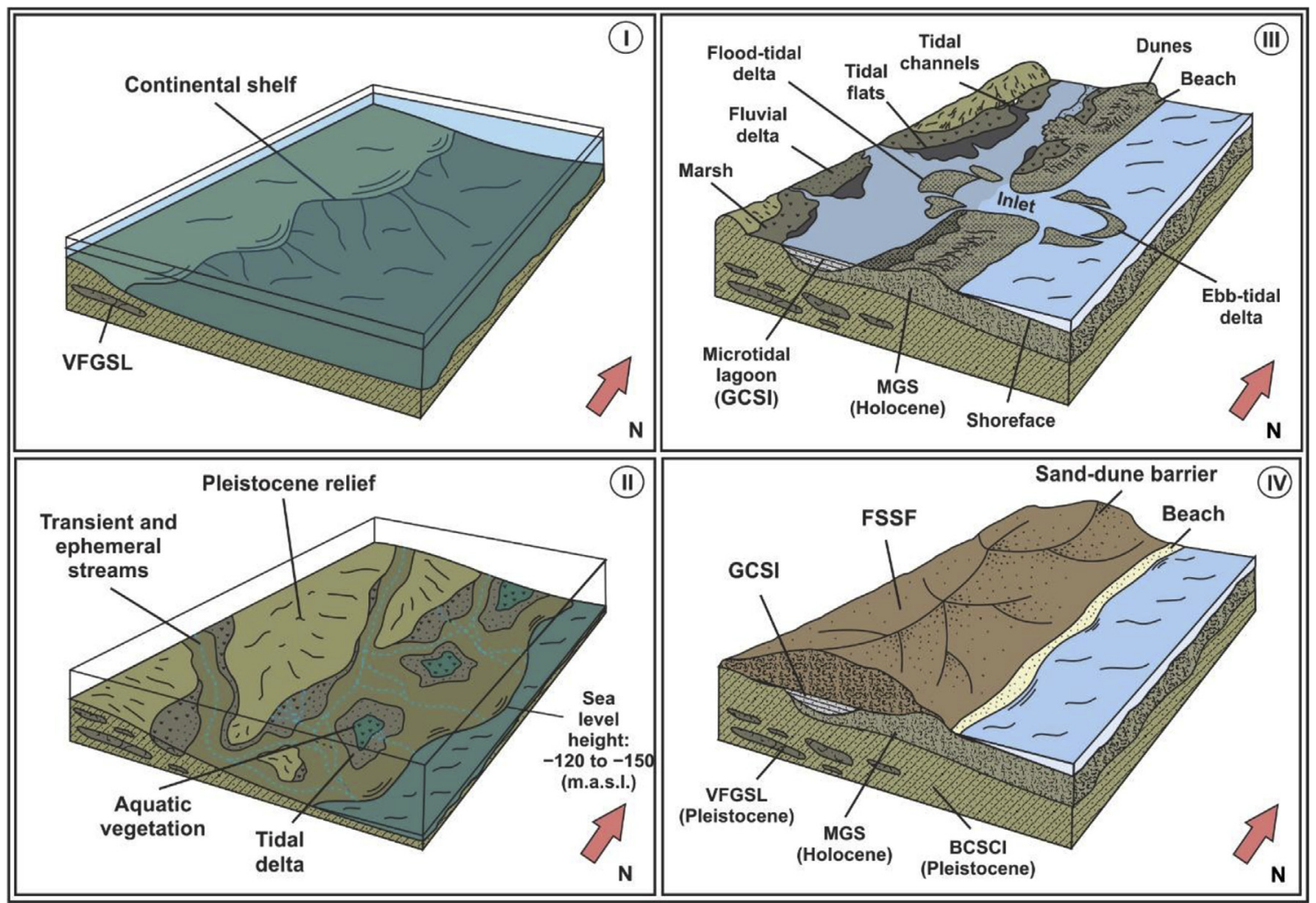

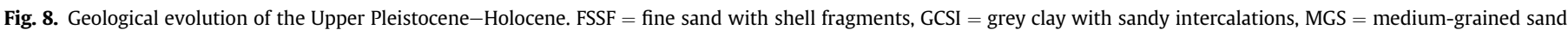
$\mathrm{BCSCI}=$ brown clayey silt with carbonate intercalations, VFGSL $=$ very fine-grained sand lenses.

record of the relict palaeo-relief, whereas VFGSL is the result of the accumulation of sediments eroded in the same depositional environment. In this way, the resulting surface constituted the substrate over which the Holocene sediments deposited.

In the early Holocene, the NE-trending deposition of the transgressive barriers corresponding to MGS occurred. These deposits constituted a topographic high that generated a coastal lagoon environment, in which GCSI deposited. The landscape for this interval (Fig. 8 III) may correspond to the inland lagoons and microtidal coasts partially isolated from the marine system. In this context, the littoral activity predominates over the continental processes, due to the vertical accretion of the transgressive barriers and/or the creation of temporary channel openings (inlets), allowing the inflow of sea water into the inland lakes or lagoons, among other landforms. On the other hand, in the sectors that are more isolated from the coastal dynamics, incipient soils and marshes, which have been described as organic horizons, may have developed. This type of environment may have occurred both during the transgression and regression processes, thus explaining the alternation of sand and clay observed in certain boreholes.

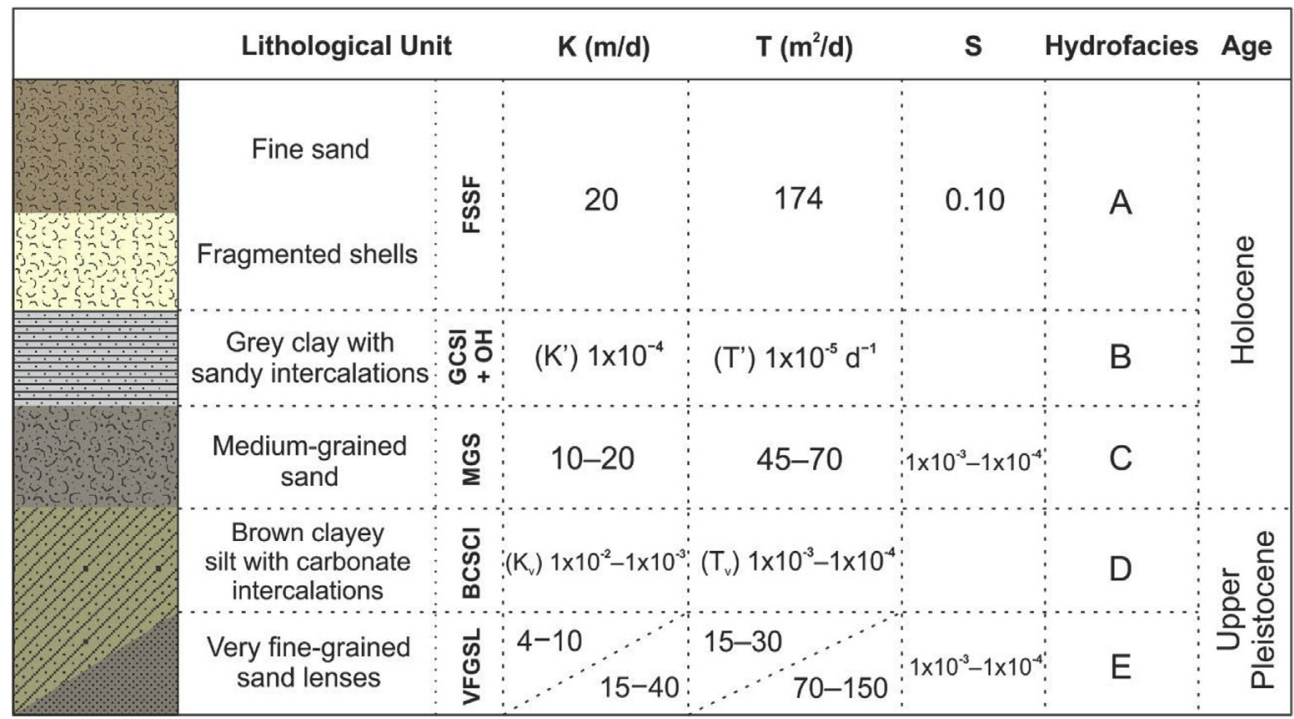

Fig. 9. Hydrogeological scheme of the study area. Hydrogeological behaviour of the hydrofacies identified. 


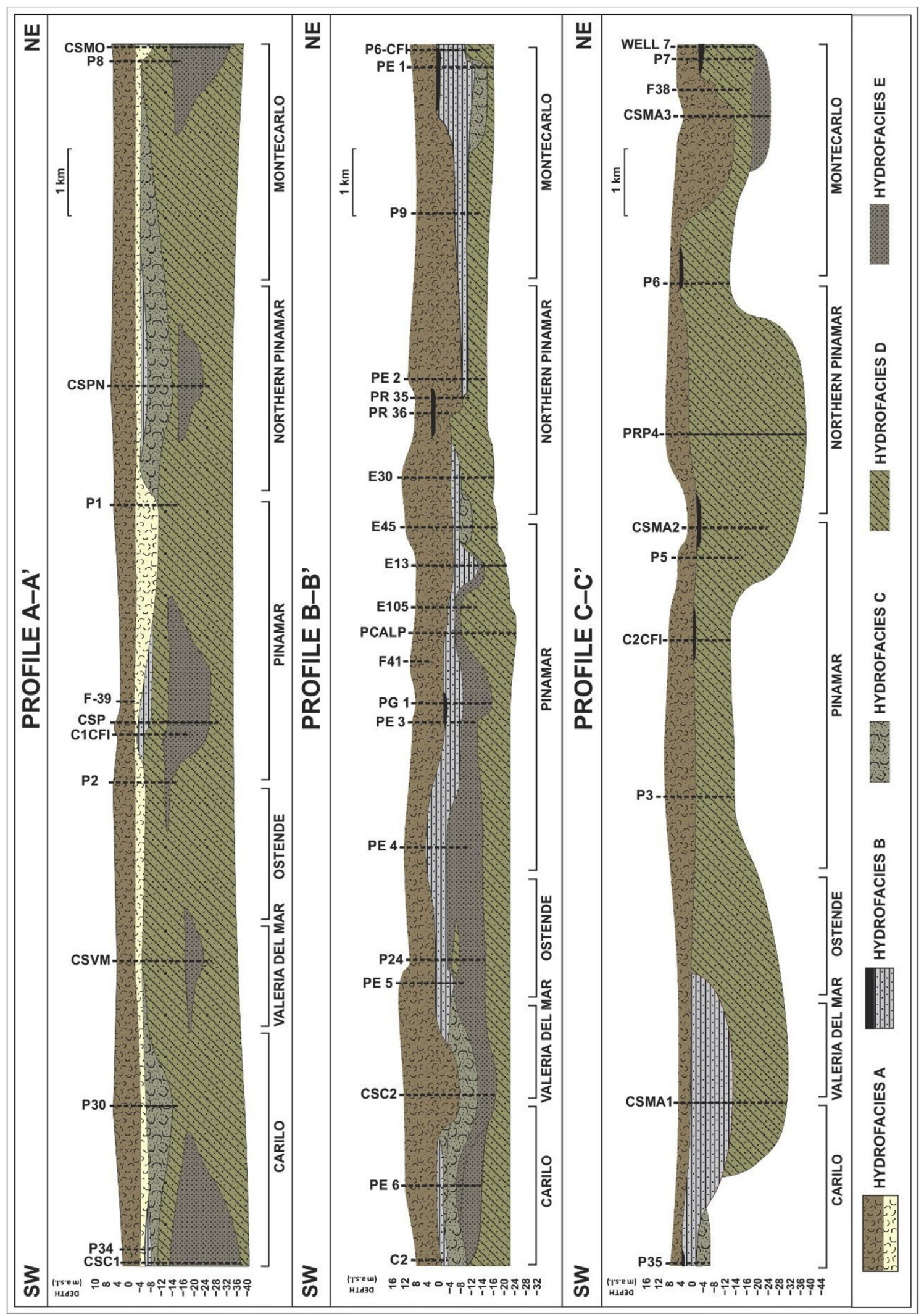

Fig. 10. Hydrogeological profiles parallel to the coastline.

The arrangement of FSSF during the last stage (Fig. 8 IV) is related to the present-day configuration of the field of coastal dunes, which is the result of the constant sediment supply.

\subsection{Hydrogeological behaviour}

As already shown, the lithological characterization based on 


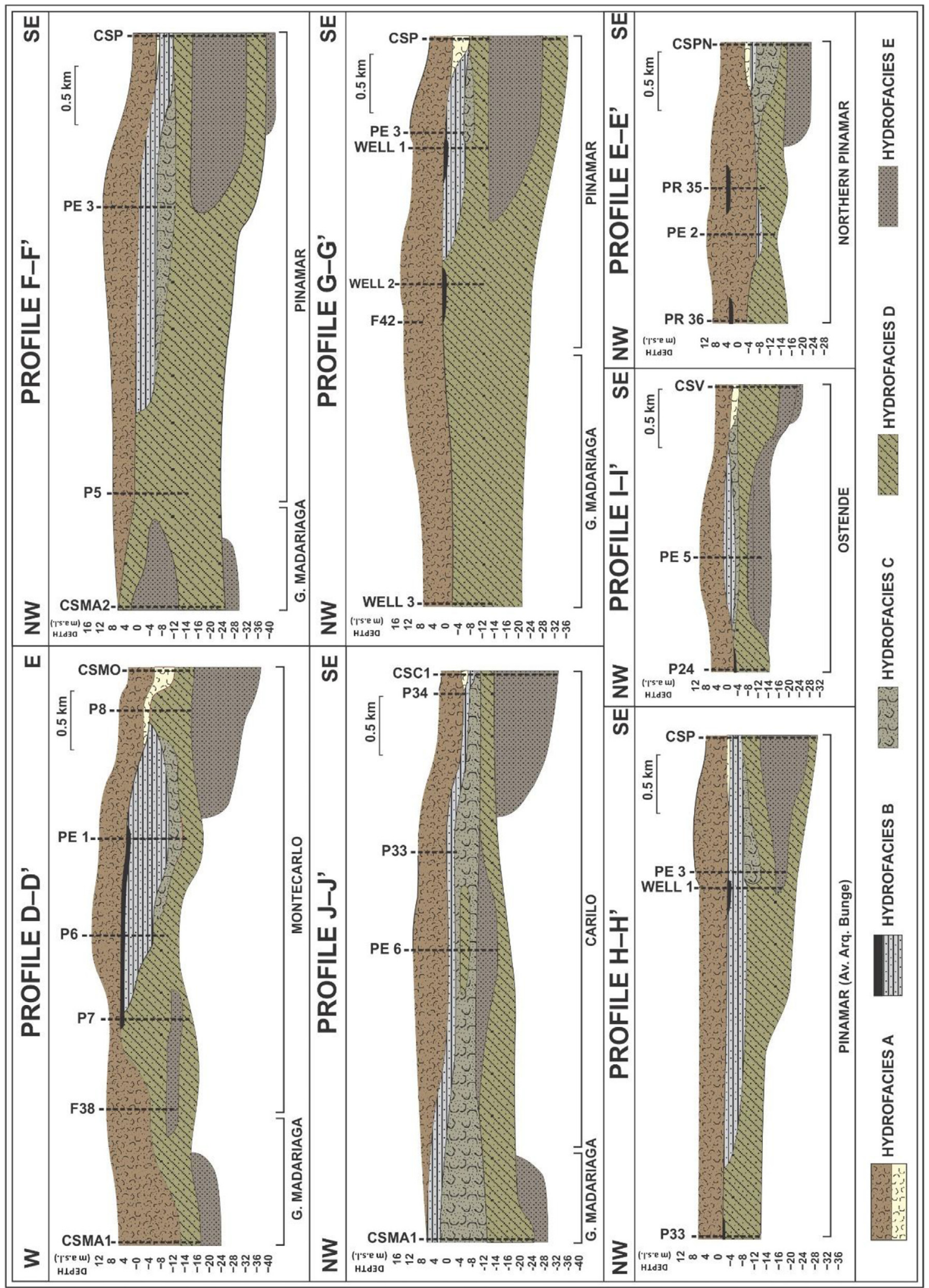

Fig. 11. Hydrogeological profiles perpendicular to the coastline.

borehole data shows alternating sand, silt, clay and combinations of such sediments.

On the basis of the sedimentary environments in which the sedimentation of the units containing the groundwater system occurred, a significant variation-both lateral and vertical-in thickness and grain-size composition can be assumed. This situation is responsible for the unconformity in the less permeable layers and it explains the variations in hydraulic connection 


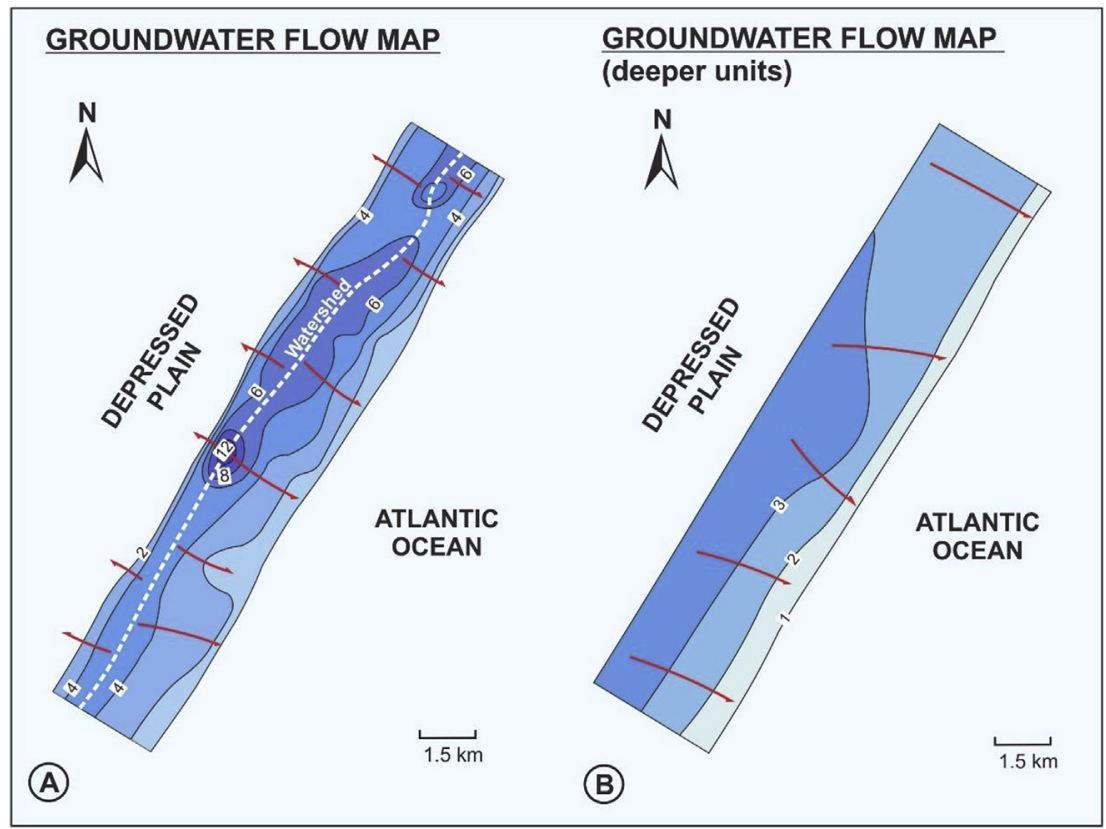

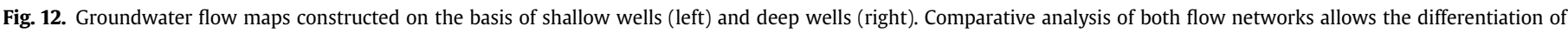
local flow (left) and regional flow (right). Isolines represent the elevation in metres of the water table above sea level.

between the most permeable layers over short distances.

Considering this situation, and in order to transform the lithological units into hydrogeological units, it was appropriate to use the term "hydrofacies", so as to simplify the system and show a direct application that would make it possible to connect the geological history with a specific hydrogeological behaviour.

This term has been used in this work in accordance with the conceptual meaning expressed by Anderson (1989), who defines it as a homogeneous but not necessarily isotropic sedimentary unit, which formed under specific conditions that lead to a particular hydrogeological behaviour. Fig. 9 shows the distribution and relationships between the hydrofacies identified on the basis of the lithological units and the typical values of transmissivity $(T)$, hydraulic conductivity $(\mathrm{K})$ and storage $(\mathrm{S})$ obtained from the pumping tests conducted.

Hydrofacies A (FSSF) includes the UZ. The hydraulic conductivity values range from 8 to $12 \mathrm{~m} / \mathrm{d}$, whereas the transmissivity values are between 110 and $130 \mathrm{~m}^{2} / \mathrm{d}$, with an estimated storage coefficient of 0.15 . The geoelectrical properties indicate resistivities that in the UZ are higher than $200 \Omega \mathrm{m}$, while in the saturated zone (SZ) the most frequent values are $20-150 \Omega \mathrm{m}$. This hydrofacies is an aquifer unit that contains the water table and is in contact with the surface hydrological processes, allowing the direct infiltration of the rainfall excess. In certain sections, it corresponds to the presentday sedimentary environment, in which the climatic and geomorphological conditions favour the accretion of the existing coastal barrier.

Hydrofacies B (GCSI $+\mathrm{OH})$ is composed of clay sediments that originated in a coastal lagoon environment. Vertical T and vertical $\mathrm{K}$ values are of the order of $1 \times 10^{-5} \mathrm{~d}^{-1}$ and $1 \times 10^{-4} \mathrm{~m} / \mathrm{d}$, respectively. The electrical resistivities observed are below $10 \Omega \mathrm{m}$. OH (palaeosols) is included in this unit due to the similarities in hydrogeological behaviour. Its hydrolithological function is that of an aquitard, with its behaviour being directly related to its variations in thickness.

Hydrofacies C (MGS) is related to the second transgressive-regressive event that occurred during the Holocene, which was characterized by the accretion of the transgressive barriers. The range of transmissivity values is between 45 and $70 \mathrm{~m}^{2} / \mathrm{d}$, whereas the hydraulic conductivity fluctuates between 10 and $20 \mathrm{~m} / \mathrm{d}$. The storage values obtained vary between $1 \times 10^{-3}$ and $1 \times 10^{-4}$. Electrical resistivities range from 20 to $60 \Omega \mathrm{m}$. From a hydrolithological point of view, it represents an aquifer unit.

Hydrofacies D, composed of BCSCI, constitutes an intermediate hydraulic conductivity medium and it represents the first transgressive-regressive cycle of the end of the Pleistocene. The tests carried out allowed the estimation of a vertical hydraulic conductivity of $1 \times 10^{-3} \mathrm{~m} / \mathrm{d}$, while the vertical transmissivity ranges are within $1 \times 10^{-3}$ and $1 \times 10^{-4} \mathrm{~d}^{-1}$. This unit may be classified as an aquitard with lateral variations depending on the degree of occurrence of clay and the relative abundance of carbonates.

Hydrofacies E is constituted by VFGSL, corresponding to the end of the Pleistocene. The hydraulic conductivity ranges estimated for the finer-grained sand variety are between 4 and $10 \mathrm{~m} / \mathrm{d}$, whereas the transmissivity fluctuates between 15 and $30 \mathrm{~m}^{2} / \mathrm{d}$. The coarser variety (clean medium-grained sand) has somewhat higher hydraulic conductivity and transmissivity ranges, with values from 15 to $40 \mathrm{~m} / \mathrm{d}$ and from 70 to $150 \mathrm{~m}^{2} / \mathrm{d}$, respectively. The values of the storage coefficient are between $1 \times 10^{-3}$ and $1 \times 10^{-4}$. This latter variety consists of lenses that constitute an aquifer and that in general have a significant areal extension.

\subsection{Hydrofacies distribution}

The hydrogeological profiles allowed the evaluation of the regional configuration of the system, as well as the arrangement of the hydrofacies (Figs. 10 and 11). In general, an irregular pattern can be observed in the distribution of the lithologies, which is made evident by the strong lateral variations. From this condition, it can be deduced that accumulation and erosion processes operated simultaneously. Besides, a greater development of the units in the central sectors of the barrier can be observed, and it is in those sectors where, in a vertical section, all of the units described may be differentiated.

Hydrofacies $A$ is the one with greater lateral continuity and it is represented by FSSF (see profiles $A-A^{\prime}, B-B^{\prime}$ and $C-C^{\prime}$ in Fig. 10); a 
typical shell fragment layer can even be recognized close to the present-day coastline (profile $A-A^{\prime}$ ), possibly the result of ancient marine abrasion platforms. The entire hydrofacies is in contact with the underlying units by means of an erosional unconformity.

In turn, hydrofacies $\mathrm{B}(\mathrm{GCSI}+\mathrm{OH})$ has its maximum expression in the central portions of the barrier, a condition that could be verified in most of the profiles, particularly in $\mathrm{B}-\mathrm{B}^{\prime}$ and $\mathrm{D}-\mathrm{D}^{\prime}$, where the thickness reaches $12 \mathrm{~m}$. In the upper part of this hydrofacies, organic horizons can frequently be observed and they constitute the record of ancient buried soils (palaeosols).

Underlying the clays described, a series of sandy layers with limited lateral development can be observed, represented by MGS (hydrofacies C). The thickness of these bodies tends to decrease towards both ends of the coastal barrier. Such a stratigraphic relationship can clearly be observed in cross-sections $\mathrm{D}-\mathrm{D}^{\prime}, \mathrm{F}-\mathrm{F}^{\prime}$, $\mathrm{J}-\mathrm{J}^{\prime}$ and $\mathrm{I}-\mathrm{I}^{\prime}$ in Fig. 11.

At the base of the system, BCSCI (hydrofacies D) can be observed, with significant vertical development and within which VFGSL (hydrofacies E) can be found. On numerous occasions, the occurrence of shell fragment layers of varying thicknesses could be identified. These were located at the base of the lenses or isolated within the clayey silt; these layers could be relict beach structures.

\subsection{Geohydrological behaviour}

This geohydrological system is characterized by its hydraulic continuity, with different degrees of connection between the aquifer units, depending on the occurrence and thickness variations of the aquitard units.

Three aquifer units that constitute the most frequent groundwater exploitation levels can be recognized: hydrofacies $\mathrm{A}, \mathrm{B}$ and $\mathrm{E}$. The latter is Upper Pleistocene in age and the other two are Holocene.

The groundwater flow of the water table (hydrofacies A) is represented by equipotential curves parallel to the coast, with a groundwater divide that tends to coincide with the maximum topographic heights of the coastal barrier and groundwater flow directions towards the east (sea) and the west (continent). The groundwater flow mostly develops between the equipotential curves of 6 and $2 \mathrm{~m}$ a.s.l., with hydraulic gradients ranging from 1 to $4 \mathrm{~m} / \mathrm{km}$ (Fig. 12 A).

The flow map of hydrofacies D and $\mathrm{E}$ also shows equipotential curves parallel to the coast as from a height of $3.5 \mathrm{~m}$ a.s.l., with a hydraulic gradient of $0.7 \mathrm{~m} / \mathrm{km}$ and a southeast flow direction towards the sea (Fig. 12 B).

The water table is recharged naturally and directly by infiltration of the rainfall excess, whereas in the deeper units it occurs indirectly by vertical infiltration from the water table, as can be deduced from the differences in hydraulic head, which is more evident in the topographically higher sectors.

As shown in Fig. 12, the comparative analysis between the flow networks for the shallower hydrofacies and for the deepest one, allows the identification of differences related to flow directions and spacing between the equipotential curves. In this sense, the flow map for shallow wells responds to local behaviours, whereas the one for the deepest hydrofacies is affected by the regional context.

\section{Conclusions}

The control exerted by the geological and geomorphological factors involved in landscape formation explains the differences regarding the lithological units identified and their associated hydrogeological behaviour (hydrofacies). The distribution of electrical resistivities in the subsurface confirms the lateral and vertical variations of such hydrogeological behaviour.

In the first $50 \mathrm{~m}$, the geological outline is composed of a base of Upper Pleistocene age represented by hydrofacies D, within which an aquifer unit constituted by hydrofacies E occurs.

The early Holocene is represented by hydrofacies $C$, which constitutes an aquifer unit, and by hydrofacies $\mathrm{B}$, which, having formed in a low energy environment, is an aquitard unit. Finally, hydrofacies A of the present-day sand-dune barrier represents the late Holocene.

To summarize, this new approach allows the differentiation of three aquifer units: hydrofacies $A$ and $C$, which constitute Holocene sedimentary cycles, and hydrofacies E, of Upper Pleistocene origin. The three aquifer units are exploited simultaneously and-depending on the occurrence and composition of the less permeable units (aquitards) constituted by hydrofacies B and $\mathrm{D}$-they represent an interconnected hydraulic system with a useful thickness of at least $50 \mathrm{~m}$.

In view of the marked population growth in this sector year after year, this research is of the utmost importance, as it opens a new horizon in the degree of hydrogeological knowledge in the region.

The approach adopted offers arguments that, within a global evolutionary framework, define the conceptual and applied basis that should be considered when developing conceptual and numerical models at local and regional scales.

\section{References}

Anderson, M.P., 1989. Hydrogeological facies models to delineate large-scale spatial trends in glacial and glaciofluvial sediments. Geol. Soc. Am. Bull. 101, 501-511.

Atkinson, L.A., Ross, M., Stumpf, A.J., 2014. Three-dimensional hydrofacies assemblages in ice-contact/proximal sediments forming a heterogeneous hybrid hydrostratigraphic unit in central Illinois, USA; Disposition tridimensionnelle des hydrofacis dans des sdiments priglaciaires formant une unit hydr. Hydrogeol. J. 22, 1605-1624. http://dx.doi.org/10.1007/s10040-014-1156-7.

Bocanegra, E., Silva, G.C., Custodio, E., Manzano, M., Montenegro, S., 2009. State of knowledge of coastal aquifer management in South America. Hydrogeol. J. 18, 261-267. http://dx.doi.org/10.1007/s10040-009-0520-5.

Caminos, R. (Ed.), 1999. Geología Argentina. Servicio Geológico Minero Argentino, vol. 29. Instituto de Geología y Recursos Minerales. Anales, Buenos Aires, p. 810.

Carol, E.S., Kruse, E., 2012. Hydrochemical characterization of the water resources in the coastal environments of the outer Río de la Plata Estuary, Argentina. J. South Am. Earth Sci. 37, 113-121. http://dx.doi.org/10.1016/j.jsames.2012.02.009.

Carretero, S., Kruse, E., 2010. Modificaciones en las áreas de recarga del acuífero freático en los médanos costeros de San Clemente del Tuyú, provincia de Buenos Aires. Rev. Asoc. Geol. Argent. 66, 466-474.

Carretero, S., Kruse, E., 2014. Impacto de la urbanización en la infiltración en un área costera, Argentina. Tecnol. Ciencias del Agua 5, 5-24.

Cavalloto, J.L., Violante, R.A., Parker, G., 2004. Sea-level fluctuations during the last 8600 years in the La Plata river (Argentina). Quat. Int. 114, 155-165.

Cavalloto, J.L., 1995. Evolución geomorfológica de la llanura costera ubicada en el margen su del Río de La Plata. Tesis Doctoral No 635. Facultad de Ciencias Naturales y Museo, Universidad nacional de La Plata, p. 237.

dell'Arciprete, D., Bersezio, R., Felletti, F., Giudici, M., Comunian, A., Renard, P., 2012. Comparison of three geostatistical methods for hydrofacies simulation: a test on alluvial sediments. Hydrogeol. J. 20, 299-311. http://dx.doi.org/10.1007/ s10040-011-0808-0.

Fidalgo, F., Colado, U.R., De Francesco, F.O., 1973. Sobre ingresiones marinas cuaternarias en los partidos de Castelli, Chascomús y Magdalena. (Provincia de Buenos Aires). V Congreso Geológico Argentino, Actas 3: 227-240.

Fray, C., Ewing, M., 1963. Pleistocene sedimentation and fauna of the Argentine Shelf. I: Wisconsin sea level as indicated in Argentine Continental Shelf sediments. Proc. Acad. Nat. Sci. Phila. 115, 113-126.

Frenguelli, J., 1957. Neozoico. En Geografía de la República Argentina. Sociedad Argentina de Estudios Geográficos. GAEA 2 (3), 1-218 (Buenos Aires).

Fucks, E., De Francesco, F., 2003. Ingresiones marinas al norte de la ciudad de Buenos Aires. Su Ordenamiento Estratigráfico. II Congreso Argentino de Cuaternario y Geomorfología. Actas: 101-103. San Miguel de Tucumán.

González, N., 2005. Los ambientes hidrogeológicos de la Provincia de Buenos Aires. Geología y Recursos Minerales de la Provincia de Buenos Aires. Relatorio del XVI Congreso Geológico Argentino, Cap. XXII, pp. 359-374 (La Plata).

Groeber, P., 1961. Contribuciones al conocimiento geológico del Delta del Paraná y alrededores. An. Com. Investig. Cient 5 (2), 9-54.

Hirata, R., Gesicki, A., Sracek, O., Bertolo, R., Giannini, P.C., Aravena, R., 2011. Relation between sedimentary framework and hydrogeology in the guarani aquifer system in Sao Paulo state, Brazil. J. South Am. Earth Sci. 31, 444-456. http:// dx.doi.org/10.1016/j.jsames.2011.03.006. 
Huggenberger, P., Siegenthaler, C., Stauffer, F., 1988. Grundwasserstro mung in Schottern; Einfluss von Ablagerungsformen auf die Verteilung der Grundwasserfliessgeschwindigkeit. Wasserwirtschaft 78 (5), 202-212.

INDEC, 2010. Censo Nacional de Poblaciones Hogares. www.indec.gov.ar (Último acceso 06/04/2015).

Isla, F.I., Espinosa, M., 1998. Modelo sedimentario de colmatación de pequeños estuarios dominados por limo, Pronvicia de Buenos Aires, 7ta Reunión Argentina de Sedimentología. Salta 24-36.

Isla, F.I., Bertola, G.R., 2005. Litoral bonaerense. In: de Barrio, R., Etcheverry, R.O., Caballé, M.F., Llambías, E. (Eds.), Geología y recursos minerales de la Provincia de Buenos Aires. Relatorio XVI Congreso Geológico Argentino, pp. 265-276. La Plata.

Jelgersma, S., Tooley, M.J., 1995. Sea-level changes during the recent geological past. J. Coast. Res. Holocene Cycles Clim. Sea Levels, Sediment. 17, 123-139.

Klingbeil, R., 1998. Outcrop Analogue Studies. Implications for Groundwater Flow and Contaminant Transport in Heterogeneous Glaciofluvial Quaternary Deposits. Dissertation. Department of Applied Geology, University of Tübingen.

Klingbeil, R., Kleineidam, S., Asprion, U., Aigner, T., Teutsch, G., 1999. Relating lithofacies to hydrofacies: outcrop-based hydrogeological characterisation of Quaternary gravel deposits. Sediment. Geol. 129, 299-310. http://dx.doi.org/ 10.1016/S0037-0738(99)00067-6.

Lowe, J.J., Walker, M.J.C., 1997. Reconstructing Quaternary Environments. PrenticeHall, p. 446.

Makkawi, M.H., 2004. Effect of porous medium heterogeneity on water flow: a stochastic hydrofacies approach. Hydrogeol. J. 12, 481-487. http://dx.doi.org/ 10.1007/s10040-004-0342-4.

Manzano, M., 2002. El papel de los acuíferos costeros en la gestión del medio natural (pp. 2017-2024). In: Bocanegra, E., Martínez, D., Massone, H. (Eds.), Groundwater and Human Development. ALSHUD, Mar del Plata.

Modis, K., Sideri, D., 2013. Geostatistical simulation of hydrofacies heterogeneity of the west thessaly aquifer systems in Greece. Nat. Resour. Res. 22, 123-138. http://dx.doi.org/10.1007/s11053-013-9200-1.

Parker, G., Violante, R.A., 1989. Geología y Geomorfología. Regiones I y II. Punta Rasa - Faro Querandí. Provincia de Buenos Aires. Conv. Cons. Fed. Inversiones Serv. Hidrogr. Nav. Inf. final 141.

Parker, G., 1990. El subsuelo del Río de La Plata. Rev. Asoc. Geol. Argent. 45 (3-4) 93-204.

Parker, G., Violante, R., Paterlini, M., 1996. Fisiografía de la Plataforma Continental.
In: Ramos, V., Turic, A. (Eds.), Geología y Recursos Naturales de la Plataforma Continental Argentina. Relatorio del XIII Congreso Geológico Argentino y 3er Congreso de Exploración de Hidrocarburos, vol. 1, pp. 1-16. Buenos Aires.

Pousa, J., Tosi, L., Kruse, E., Guaraglia, D., Bonardi, M., Mazzoldi, A., Rizzetto, F., Schnack, E., 2007. Coastal processes and environmental hazards: the Buenos Aires (Argentina) and Venetian (Italy) littorals. Environ. Geol. 51, 1307-1316. http://dx.doi.org/10.1007/s00254-006-0424-9.

Rolleri, E., 1975. Provincias geológicas bonaerenses. VI congreso geológico argentino, relatorio. Bahía Blanca 29-54.

Scheibe, T.D., Freyberg, D.L., 1990. Impacts of geological structure on transport: creating a data base. In: Parameter Identification and Estimation for Aquifer and Reservoir Characterization. Proceedings of the 5th Canadian=American Conference on Hydrology, pp. 56-71. Calgary.

Schnack, E., Isla, F., De Francesco, F., Fucks, E., 2005. Estratigrafía del Cuaternario marino Tardío en la provincia de Buenos Aires. In: de Barrio, R.E., Etcheverry, R.O., Caballé, M.F., Llambías, E. (Eds.), Geología y recursos minerales de la Provincia de Buenos Aires, 16to Congreso Geológico Argentino, Relatorio, pp. 159-182 (La Plata).

Schnack, E.J., Pousa, J.L., Isla, F.I., 2000. Las fluctuaciones del nivel del mar durante el Cuaternario Revista Museo de La Plata, 3 (16), 79-87.

Schneider, J.C., Kruse, S.E., 2006. Assessing selected natural and anthropogenic impacts on freshwater lens morphology on small barrier Islands: dog Island and St. George Island, Florida, USA. Hydrogeol. J. 14, 131-145. http://dx.doi.org/ 10.1007/s10040-005-0442-9.

Silva-Filho, E.V., Sobral Barcellos, R.G., Emblanch, C., Blavoux, B., Sella, S.M., Daniel, M., Simler, R., Wasserman, J.C., 2009. Groundwater chemical characterization of a Rio de Janeiro coastal aquifer, SE - Brazil. J. South Am. Earth Sci. 27, 100-108. http://dx.doi.org/10.1016/j.jsames.2008.11.004.

Spagnuolo, J.O., 2005. Evolución geológica de la región costera-marina de Punta Alta, Provincia de Buenos Aires. PhD thesis. Departamento de Geología, Universidad del Sur, p. 269.

Tosi, L., Kruse, E.E., Braga, F., Carol, E.S., Carretero, S.C., Pousa, J.L., Rizzetto, F., Teatini, P., 2013. Hydro-morphologic setting of the Samborombón Bay (Argentina) at the end of the 21st century. Nat. Hazards Earth Syst. Sci. 13, 523-534. http://dx.doi.org/10.5194/nhess-13-523-2013.

White, I., Falkland, T., 2009. Management of freshwater lenses on small Pacific islands. Hydrogeol. J. 18, 227-246. http://dx.doi.org/10.1007/s10040009-0525-0. 